\title{
EFEK HEPATOPROTEKTOR DARI EKSTRAK ETANOL DAUN JOHAR (Cassia siamea LAMK.) PADA TIKUS (Rattus norvegicus)
}

\author{
Safriani Rahman, Rachmat Kosman, Andi Cassia Siamea \\ Fakultas Farmasi Universitas Muslim Indonesia, Makassar \\ Email: safriani.rahman@umi.ac.id
}

\begin{abstract}
Johar leaf has been empirically used as malaria and hepatitis medicine. This research aims to determine hepatoprotective effect of ethanol extract of Johar leaves (Cassia siamea Lamk.) of rats liver. This research used 15 tested rats divided into 5 groups, group I was given Na.CMC 1\% (negative control), group II ethanolic extract of Johar leaves of $50 \mathrm{mg} / \mathrm{kgBB}$, group III ethanolic extract of Johar leaves of 250 $\mathrm{mg} / \mathrm{kgBB}$, group IV ethanolic extract of Johar leaves of $500 \mathrm{mg} / \mathrm{kgBB}$, and group $\mathrm{V}$ as a comparison given suspension curliv ${ }^{\circledR}$ of $42,86 \mathrm{mg} / \mathrm{kgBB}$. Giving suspension curliv $^{\circledR}$ was orally done once a day for 7 days. On the 8th day, the experimental rats were given paracetamol suspension dosage of $2,5 \mathrm{~g} / \mathrm{kgBB}$. Measurements of SGPT content was done before therapy (normal), after therapy, and after administration of paracetamol. The results showed that the ethanolic extract of Johar leaves with the dose of 50; 250; $500 \mathrm{mg} / \mathrm{kgBB}$ have a hepatoprotective effect and dose is 500 $\mathrm{mg} / \mathrm{kgBB}$ which was not statistically significantly different from curliv ${ }^{\circledR}$.
\end{abstract}

Key words: Hepatoprotective, johar leaf, SGPT.

\section{PENDAHULUAN}

Hati merupakan organ terbesar yang memiliki kumpulan sel reaktan kimia terbesar di dalam tubuh sehingga dapat mengolah dan mensintesis berbagai zat yang diangkut ke bagian tubuh lainnya. ${ }^{4}$ Hepar merupakan gerbang semua bahan yang masuk ke dalam tubuh melalui saluran cerna, sehingga sangat rentan terhadap gangguan metabolik, toksik dan mikroba. ${ }^{10}$ Hati juga merupakan pusat metabolisme tubuh yang memegang peranan penting terutama dalam hal metabolisme karbohidrat, protein dan asam lemak. ${ }^{11} \quad$ Metabolisme menunjukkan perubahan kimiawi yang terjadi di dalam tubuh untuk pelaksanaan berbagai fungsi vitalnya.

Dalam proses metabolisme, hati sering terpajan obat, zat kimia dan virus. ${ }^{3}$ Zat kimia yang masuk akan mengalami detoksifikasi dan inaktivasi sehingga menjadi tidak berbahaya bagi tubuh. Terpajannya hati oleh zat 
Efek hepatoprotektor dari ekstrak etanol daun johar (Cassia siamea LAMK.) pada tikus (Rattus norvegicus)

kimia pada kadar tertentu tidak akan merusak hati karena dengan segera hati akan melakukan regenerasi selselnya. Tetapi jika hal ini berlangsung terus menerus maka kemampuan sel hati untuk beregenerasi akan hilang dan selanjutnya akan mengalami kerusakan sel hati yang permanen sehingga dapat berakibat fatal. $^{9}$ Kerusakan sel hati selain yang disebabkan oleh virus, juga dapat disebabkan oleh obat-obatan, misal penggunaan obat dalam jangka waktu yang cukup lama seperti penggunaan paracetamol yang dikonsumsi dalam dosis berlebihan sampai mencapai dosis toksik sehingga menyebabkan hepatotoksisitas. ${ }^{5}$

Berbagai usaha yang telah dilakukan oleh masyarakat dalam menanggulangi atau mengobati penyakit hati. Salah satunya adalah penggunaan obat tradisional mengingat obat sintetik memiliki efek samping yang lebih besar dibanding obat tradisional. Selain itu, harganya jauh lebih murah dan mudah dalam memperolehnya. Oleh karena itu, obat tradisional masih banyak diminati seiring perkembangan penelitian berjalan sangat cepat, antara lain dipacu oleh beberapa hal seperti diperlukannya senyawa-senyawa untuk mengatasi berbagai macam penyakit seperti AIDS, kanker, dan juga senyawa obat yang bersifat sebagai hepatoprotektif. ${ }^{2}$

Salah satu tanaman yang biasa digunakan oleh masyarakat sebagai obat yaitu tanaman johar (Cassia siamea Lamk.) atau juar yang secara empirik telah digunakan sebagian besar masyrakat Indonesia sebagai obat malaria dan sebagian masyarakat di beberapa daerah digunakan untuk mengobati penyakit kuning atau hepatitis. Tanaman juar telah diteliti kandungan kimia oleh (Lakshmi, 2013 dan Wahjoedi, 1996) mengandung mengandung alkaloid, flavanoid, tannin, galat, steroid, lupeol, chyrsopanol, cassiamin A, siameadin, lupeone, chrysopanolantrone, barakol cassia chromone (5-acetonyl-77hydroxy-2-methylchromone), pcoumaric acid, apigenin-7-sitosterol. ${ }^{1,8}$ Senyawa flavanoid dalam tanaman memiliki aktivitas antioksidan dimana antioksidan ini dapat menghambat terjadinya kerusakan hati. ${ }^{1}$ Salah satu tanaman yang mengandung senyawa antioksidan adalah daun johar (Cassia siamea Lamk.) diduga dapat menghambat terjadinya kerusakan oksidatif pada hati. Pada penelitian lain daun johar telah diteliti oleh Wahjoedi (1994) bahwa infus daun johar menunjukkan efek 
Efek hepatoprotektor dari ekstrak etanol daun johar (Cassia siamea LAMK.) pada tikus (Rattus norvegicus)

hepatoprotektor terhadap hati tikus putih akibat pemberian karbontetraklorida. ${ }^{13}$

Berdasarkan hal tersebut, maka akan dilakukan penelitian tentang efek hepatoprotektor dari ekstrak etanol daun johar (Cassia siamea Lamk.) terhadap tikus putih (Rattus norvegicus) jantan.

\section{METODE PENELITIAN}

\section{Alat dan Bahan}

Alat yang digunakan dalam penelitian ini adalah batang pengaduk, cawan porselin, corong (Pyrex), gelas arloji, gelas kimia, gelas ukur, hair dryer (sayota), mikropipet (Huawei), pipa kapiler, restainer, sentrifuge (PLC Series), sendok besi, stirer, spoit, spektroskopi (human analyzer, microlab 300), tabung eppendorf, timbangan analitik (Ohaus), timbangan hewan, toples dan vial. Bahan yang diguanakan dalam penelitian ini adalah aquadest, curliv ${ }^{\circledR}$, daun johar (Cassia siamea Lamk.), etanol $70 \%$, kapas, Na. CMC (Natrium Carboxy Methyl Cellulose), paracetamol, pereaksi uji SGPT (Elithech) dan tissue.

\section{Prosedur kerja}

Simplisia yang digunakan adalah daun johar (Cassia siamea Lamk) yang berasal dari kota palopo Sulawesi Selatan. Determinasi tumbuhan dilakukan di laboratorium
Farmakognosi-Fitokimia Fakultas Farmasi Universitas Muslim Indonesia. Proses pengolahan bahan meliputi pengumpulan, sortasi kering, pencucian, sortasi basah, pengeringan, dan penggilingan. Selanjutnya simplisia dimaserasi dengan etanol $70 \%$ dan ekstrak diuapkan dengan rotavapor sehingga diperoleh ekstrak kental. Sediaan uji ekstrak etanol daun johar (EEDJ) yang dibuat adalah dengan dosis 50 $\mathrm{mg} / \mathrm{kgBB} ; 250 \mathrm{mg} / \mathrm{kgBB}$ dan 500 $\mathrm{mg} / \mathrm{kgBB}$.

Kelompok hewan uji terdiri dari 15 ekor tikus wistar jantan yang dibagi dalam

5 kelompok yaitu (1) kelompok kontrol (Na.CMC 1\% b/v), (2) kelompok ekstrak etanol daun johar dengan dosis $50 \mathrm{mg} / \mathrm{kgBB}$, kelompok ekstrak daun johar dosis $250 \mathrm{mg} / \mathrm{kgBB}$, (4) kelompok ekstrak etanol daun johar dosis $500 \mathrm{mg} / \mathrm{kgBB}$, dan (5) kelompok pembanding Curliv ${ }^{\circledR}$ 42,86 mg/kgBB . Pemberian dilakukan secara oral sebanyak satu kali sehari selama 7 hari. Sebelum perlakuan, semua hewan uji diinduksi dengan parasetamol 2,5 gram/KgBB secara oral. Parameter yang digunakan adalah pengukuran kadar SGPT.

Pengambilan darah dilakukan sebelum perlakuan, setelah induksi, dan setelah terapi ekstrak. Darah 
Efek hepatoprotektor dari ekstrak etanol daun johar (Cassia siamea LAMK.) pada tikus (Rattus norvegicus)

diambil melalui vena lateralis ekor sebanyak $1 \mathrm{ml}$ dan ditampung dalam tabung eppendorf, kemudian disentrifuge selama 10 menit dengan kecepatan $10000 \mathrm{rpm}$ pada suhu $25^{\circ} \mathrm{C}$. serum diambil dan selanjutnya dilakukan pengukuran kadar SGPT menggunakan human analyzer.

\section{HASIL PENELITIAN}

Tabel. 1. Rata-rata pengukuran kadar SGPT tikus putih (Rattus norvegicus) yang diukur pada keadaan awal, pemberian ekstrak dan setelah pemberian paracetamol.

\begin{tabular}{ccccc}
\hline $\begin{array}{c}\text { Kelompok } \\
\text { Perlakuan } \\
\text { (mg/kg BB) }\end{array}$ & Awal & Terapi & Induksi & $\begin{array}{c}\text { Selisih SGPT Terapi dan } \\
\text { Induksi }\end{array}$ \\
\cline { 2 - 5 } & & & & $305,16 \pm 15,10$ \\
Na. CMC & $39,46 \pm 1,78$ & $40,33 \pm 1,23$ & $345,5 \pm 16,33$ & $58,06 \pm 8,97$ \\
EE DJ 50 & $50,1 \pm 1,95$ & $49,96 \pm 7,54$ & $108,03 \pm 7,54$ & $49,40 \pm 9,33$ \\
EE DJ 250 & $54,63 \pm 0,75$ & $49,96 \pm 2,55$ & $99,36 \pm 7,12$ & $24,10 \pm 1,21$ \\
EE DJ 500 & $58,8 \pm 0,72$ & $50,7 \pm 1,47$ & $74,80 \pm 1,67$ & $28,40 \pm 5,13$ \\
Curliv® 42,86 & $46,33 \pm 0,75$ & $39,2 \pm 4,15$ & $67,60 \pm 3,72$ & \\
\hline
\end{tabular}

Tabel 2. Analisis Varian (ANOVA) One Way Kadar SGPT

\begin{tabular}{lc}
\hline Kelompok perlakuan & $\mathbf{p}<\mathbf{0 , 0 5}$ \\
\hline Kel 1. Na.CMC & \\
Kel 2. EEDJ $50 \mathrm{mg} / \mathrm{kgBB}$ \\
Kel 3. EEDJ $250 \mathrm{mg} / \mathrm{kgBB}$ \\
Kel 4. EEDJ $500 \mathrm{mg} / \mathrm{kgBB}$ \\
Kel 5. Curliv®
\end{tabular}

Tabel 3. Uji lanjutan LSD Selisih Kadar SGPT Terapi-Induksi

\begin{tabular}{ccc}
\hline Kelompok Perlakuan & $\mathbf{P}$ & Ket. \\
\hline $1-2$ & 0,000 & $\mathrm{~S}$ \\
$1-3$ & 0,000 & $\mathrm{~S}$ \\
$1-4$ & 0,000 & $\mathrm{~S}$ \\
$1-5$ & 0,000 & $\mathrm{~S}$ \\
$2-3$ & 0,276 & $\mathrm{NS}$ \\
$2-4$ & 0,001 & $\mathrm{~S}$ \\
$2-5$ & 0,003 & $\mathrm{~S}$ \\
$3-4$ & 0,007 & $\mathrm{~S}$ \\
$3-5$ & 0,019 & $\mathrm{~S}$ \\
$4-5$ & 0,580 & $\mathrm{NS}$ \\
\hline Ket & p 0,05 menunujukkan signifikan (Berbeda nyata) \\
p $>0,05$ menunjukkan non signifikan (tidak berbeda nyata) & \\
$1=$ Na.CMC & & \\
2 = EEDJ 50 mg/kgBB & & \\
$3=$ EEDJ 250 mg/kgBB & & \\
4 & $=$ EEDJ 500 mg/kgBB &
\end{tabular}


Efek hepatoprotektor dari ekstrak etanol daun johar (Cassia siamea LAMK.) pada tikus (Rattus norvegicus)

\section{PEMBAHASAN}

Pada tabel 1 terlihat nilai ratarata SGPT awal, SGPT terapi, SGPT akhir dan selisih SGPT akhir dan terapi. Hasil pengamatan secara kuantitatif terdapat peningkatan kadar SGPT di atas kadar normal pada kelompok perlakuan hal ini diduga karena beberapa faktor yaitu faktor makanan, faktor tinggi karbohidrat, stress dan hewan coba yang tidak specific pathogen free (SPF). ${ }^{6}$ Pada saat terapi kadar SGPT tikus mengalami penurunan diduga karena kandungan flavanoid dalam ekstrak etanol daun johar. Setelah diinduksi paracetamol kadar SGPT akhir tikus meningkat 2-3 kali lipat dari kadar awal. Ini menunjukkan adanya kerusakan pada hati tikus yang telah diinduksi paracetamol. hepatotoksisitas parasetamol disebabkan karena adanya pembentukan metabolit toksik ketika bagian dari parasetamol diaktifkan oleh sitokrom P-450 menjadi metabolit $\mathrm{N}$-asetil-P-benzoquinon imina (NAPQI) yang sangat reaktif. NAPQI awalnya didetoksifikasi melalui konjugasi dengan glutation yang direduksi (GSH) untuk membentuk asam mercapturic. Namun, ketika tingkat pembentukan NAPQI melebihi tingkat detoksifikasi oleh GSH, ini akan mengoksidasi jaringan makromolekul seperti lipid atau kelompok protein dan mengubah homeostasis kalsium setelah GSH semakin menipis. ${ }^{7}$

\section{Berdasarkan}

perhitungan statistik dengan menggunakan uji one way Anova dan dilanjutkan dengan uji LSD menunjukkan bahwa kadar SGPT kelompok Na.CMC dengan ekstrak etanol daun johar $50 \mathrm{mg} / \mathrm{kgBB}, 250$ $\mathrm{mg} / \mathrm{kgBB}, 500 \mathrm{mg} / \mathrm{kgBB}$ dan curliv $^{\circledR}$ menunjukkan hasil berbeda nyata $(p>$ 0,05). Kelompok ekstrak etanol 50 $\mathrm{mg} / \mathrm{kgBB}$ dan $250 \mathrm{mg} / \mathrm{kgBB}$ menunjukkan hasil yang tidak berbeda nyata $(p<0,05)$. Kelompok ekstrak $500 \mathrm{mg} / \mathrm{kgBB}$ dengan kelompok curliv ${ }^{\circledR}$ menunjukkan hasil tidak berbeda nyata $(p<0,05)$. Dengan demikian dapat disimpulkan bahwa dosis ekstrak etanol daun johar dosis 50 mg/kgBB; 250 mg/kgBB; 500 $\mathrm{mg} / \mathrm{kgBB}$ memiliki aktivitas hepatoprotektor namun yang paling efektif adalah dosis $500 \mathrm{mg} / \mathrm{kgBB}$ karena secara statistik tidak berbeda nyata dengan pembanding yang diberi suspense curliv ${ }^{\circledR}$. Aktivitas hepatoprotektor ekstrak etanol daun johar diduga karena kandungan flavanoid yang bersifat sebagai antioksidan yang mampu memberikan efek perlindungan pada sel hati. 
Efek hepatoprotektor dari ekstrak etanol daun johar (Cassia siamea LAMK.) pada tikus (Rattus norvegicus)

\section{KESIMPULAN}

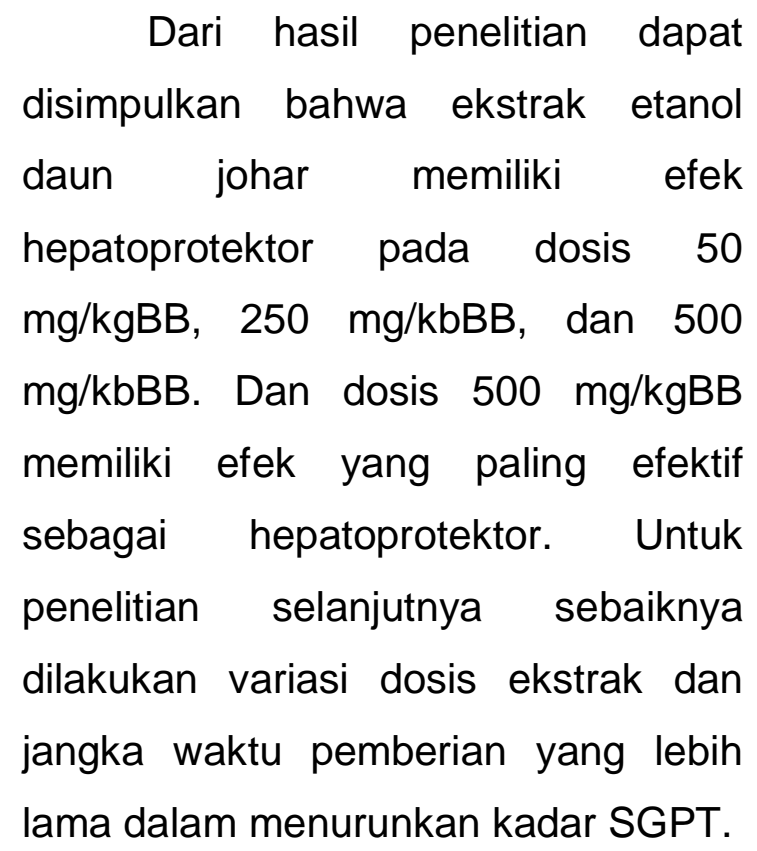

\section{DAFTAR PUSTAKA}

1. Alan L, Miller ND. Antioxidant flavanoids: Structure, Function and Clinical Usage. Alt Med Rev 1996;1(2):103-111.

2. Armansyah dkk. Aktivitas Hepatoprotektif Ekstrak Etanol Daun Kucing-kucingan (Acalypha indical L.) pada Tikus Putih (Rattus norvegicus) yang diinduksi Parasetamol. 2010.

3. Day CP, Fontana RJ, Seeff LB, Andrade RJ, Msson EB, Serrano C, et al. Meeting report: Standardization of Nomenclature and Causality Assessment in DrugInduced Liver Injury: Summary of a Clinical Research Workshop. Hepatology 2010; 52:730-742.

4. Guyton AC.. Buku Ajar Fisiologi Kedokteran Ed ke-11. Jakarta : Buku Kedokteran EGC; 2007.

5. Hartono, Ida Nurmiati. Pengaruh Ekstrak Rimpang Kunyit (Curcuma domestica) terhadap Peningkatan Kadar SGOT dan SGPT Tikus Putih Akibat Pemberian Asetaminofen. Biofarmasi 32005 ;(2):57-60

6. Irawati, Erlin. Efek Hepatoprotektif Ekstrak Daun Kemunting terhadap Hepatotoksisitas yang diinduksi Paracetamo. Pontianak : Fakultas Kedokteran Universitas Tanjung Pura; 2014.

7. Kanchana N, Sadiq AM. Hepatoprotective effect of Plumbago zeylanica On Paracetamol Induced Liver Toxicity In Rtas 2012;3(1):151-154.

8. Lakshmi, Ganga Rao Battu, Ravi Kumar. Evaluation of in vitro AntiBacterial Activity of Cassia Siamea Leaves. 2013.

9. Raflizar, 2009. Dekok Daun Paliasa (Kleinhovia hospita Linn) Sebagai Obat Radang Hati Akut.

10. Robbins SL, Kumar V, Cotran SR. Buku Ajar Patologi Robbins Ed 7. Jakarta: EGC; 2007.

11.Sudoyo, A.W, dkk. Buku Ajar IImu Penyakit Dalam. Jakarta : Interna Publishing;2009.

12. Wahjoedi, Astuti YN. Penelitian Toksisitas Subkronik Infus Daun Johar (Cassia siamea Lamk) Pada Tikus Putih. Jakarta : Pusat Penelitian dan Pengembangan Farmasi Badan Litbangkes;1996.

13. Wahjoedi B, Azizahwati, Sumitro. Infus daun johar (Cassia siamea /Lamk.) sebagai hepatoprotektor pada tikus putih. Warta Himpunan Kimia Klinik Indonesia; 1994. 